\title{
Patient blood management (PBM) in pregnancy and childbirth: literature review and expert opinion
}

\author{
Daniel Surbek ${ }^{1}$ (D) $\cdot$ Yvan Vial $^{3} \cdot$ Thierry Girard $^{4} \cdot$ Christian Breymann $^{5} \cdot$ Gabriela Amstad Bencaiova $^{2} \cdot$ David Baud $^{3}$. \\ René Hornung $^{6} \cdot$ Behrouz Mansouri Taleghani $^{7} \cdot$ Irene Hösli $^{2}$
}

Received: 29 July 2019 / Accepted: 31 October 2019 / Published online: 14 November 2019

(c) The Author(s) 2019

\begin{abstract}
Purpose Patient blood management [PBM] has been acknowledged and successfully introduced in a wide range of medical specialities, where blood transfusions are an important issue, including anaesthesiology, orthopaedic surgery, cardiac surgery, or traumatology. Although pregnancy and obstetrics have been recognized as a major field of potential haemorrhage and necessity of blood transfusions, there is still little awareness among obstetricians regarding the importance of PBM in this area. This review, therefore, summarizes the importance of PBM in obstetrics and the current evidence on this topic.

Method We review the current literature and summarize the current evidence of PBM in pregnant women and postpartum with a focus on postpartum haemorrhage (PPH) using PubMed as literature source. The literature was reviewed and analysed and conclusions were made by the Swiss PBM in obstetrics working group of experts in a consensus meeting.

Results PBM comprises a series of measures to maintain an adequate haemoglobin level, improve haemostasis and reduce bleeding, aiming to improve patient outcomes. Despite the fact that the WHO has recommended PBM early 2010, the majority of hospitals are in need of guidelines to apply PBM in daily practice. PBM demonstrated a reduction in morbidity, mortality, and costs for patients undergoing surgery or medical interventions with a high bleeding potential. All pregnant women have a significant risk for PPH. Risk factors do exist; however, $60 \%$ of women who experience PPH do not have a pre-existing risk factor. Patient blood management in obstetrics must, therefore, not only be focused on women with identified risk factor for PPH, but on all pregnant women. Due to the risk of PPH, which is inherent to every pregnancy, PBM is of particular importance in obstetrics. Although so far, there is no clear guideline how to implement PBM in obstetrics, there are some simple, effective measures to reduce anaemia and the necessity of transfusions in women giving birth and thereby improving clinical outcome and avoiding complications.

Conclusion PBM in obstetrics is based on three main pillars: diagnostic and/or therapeutic interventions during pregnancy, during delivery and in the postpartum phase. These three main pillars should be kept in mind by all professionals taking care of pregnant women, including obstetricians, general practitioners, midwifes, and anaesthesiologists, to improve pregnancy outcome and optimize resources.
\end{abstract}

Keywords Patient blood management $\cdot$ PBM $\cdot$ Outcome $\cdot$ Improve $\cdot$ Perinatal haemorrhage $\cdot$ PPH $\cdot$ Pregnancy $\cdot$ Obstetrics

Daniel Surbek

daniel.surbek@insel.ch

1 Department of Obstetrics and Gynaecology, Bern University Hospital, Insel Hospital, University of Bern, Friedbühlstrasse 19, 3010 Bern, Switzerland

2 Clinic of Obstetrics and Gynaecology, University Hospital Basel, Basel, Switzerland

3 Service of Obstetrics, Department Woman-Mother-Child, University Hospital (CHUV) and University of Lausanne (UNIL), Lausanne, Switzerland
4 Department of Anaesthesiology, University Hospital Basel, Basel, Switzerland

5 Obstetric Research-Feto Maternal Haematology Unit, University Hospital Zurich, Zurich, Switzerland

6 Department of Obstetrics and Gynaecology, St. Gallen Cantonal Hospital, St. Gallen, Switzerland

7 Department of Haematology, Inselspital, University and University Hospital Bern, Bern, Switzerland 


\section{Introduction}

Patient blood management (PBM) has recently been introduced in several areas in medicine. It comprises a series of measures and methods to maintain an optimal haemoglobin $(\mathrm{Hb})$ level, optimise haemostasis, minimise blood loss, and limit blood transfusions aiming to improve patient outcomes. Recent studies have shown that the use of PBM minimizes perioperative bleeding, reduces the requirement of blood transfusion [1-8], perioperative morbidity [1-4], mortality, duration of hospitalization $[1,4]$, and costs $[9,10]$. Regarding this, the World Health Organization (WHO) was recommending since 2010 to urgently implement PBM [11]. Some hospitals have already successfully implemented PBM notably in Australia [7], Europe [2, 4-6], United States [3], and also in Asia. However, many obstetricians and obstetrical departments still are in need of guidance for the implementation of PBM in daily clinical practice. Despite the demonstrated benefits, challenges and mindsets limit the implementation of PBM guidelines into daily medical practice [12]. These challenges can be due to ignorance, lack of cross-functional engagement, limited resources, and miss conception of PBM benefits, which may even create a fear of job loss in blood donor service or transfusion medicine.

Introducing PBM in a hospital requires that the involved physicians and health care providers give up the sometimes-dogmatic idea that blood transfusions are the first line treatment to correct low haemoglobin values. PBM is based on three pillars (Table 1): (1) anticipation, detection, and correction of preoperative/prepartum anaemia; (2) prevention and reduction of perioperative/ peripartum red blood cell (RBC) loss; and (3) optimizing postoperative/postpartum treatment of anaemia, including the restrictive use of red blood cell transfusions. Probably, the most difficult task is to convince hospital leaders of the importance of PBM and to change the culture of medical management among colleagues.

\section{Method}

With this literature review, we aimed to identify: (a) the patient at risk of PPH; (b) the need of PBM in obstetrics; and (c) PBM programs implementation in the field of obstetrics. The rationale for this literature review was to identify gaps in knowledge and to provide recommendations for the improvement of antenatal care for health care professionals in this crucial and fast evolving field of patient blood management.

Databases searched included PubMed, Scopus, CINAHL, Google, WHO guidelines database, Cochrane Library, and Web of Science, using search terms: PBM, PBM in obstetrics, blood transfusion, volume management, anaemia in pregnancy, and PPH. In total, 1250 articles were screened. Among them, 410 were relevant for this review.

\section{Results and discussion}

\section{Challenges of PBM in obstetrics}

Due to the risk of postpartum haemorrhage (PPH), which is inherent to every pregnancy, PBM is of particular importance for obstetrics. Implementation of PBM in obstetrics provides the opportunity to minimise bleeding and blood transfusions. However, large well-designed clinical studies are missing in this field.

It is more challenging to implement PBM in obstetrics than in other specialties. Furthermore, personnel, commodities, infrastructure, and a universal access to comprehensive obstetric care for the pregnant women are prerequisites [13]. In obstetrics, there are several guidelines for the management of PPH. Most management recommendations are similar; only minor differences exist due to the lack of published solid clinical outcomes. Comparing guidelines for PPH in different obstetrical societies and international groups, there are important differences regarding RBC transfusions and PBM [14].

Challenges of PBM include identification of women at high risk (patient in whom PPH is likely to occur and where

Table $1 \mathrm{PBM}$ in obstetrics requires medical and surgical/interventional strategies for prevention and treatment of PPH

\begin{tabular}{ll}
\hline Medical strategies & Surgical/interventional strategies
\end{tabular}

Pre-partum

Correction of anaemia

Intra-partum

Uterotonics [PPH prevention and treatment]

Active coagulation management in PPH (Tranexamic acid, Fibrinogen, FFP)

Post-partum

Correction of anaemia

Avoid unnecessary blood transfusions
Surgical technique minimizing blood loss (prevention of PPH)

Balloon catheter

Compression sutures

Embolisation

Cell salvage and autologous transfusion 
$\mathrm{RBC}$ transfusion constitutes the standard of care), implementation of medical and surgical/interventional strategies, and restrictive but clinical appropriate blood transfusion in patients who need it. A multidisciplinary approach is prerequisite for the success of PBM in obstetrics, including midwives, obstetricians, anaesthetists, interventional radiologists, and haematologists. Albeit PBM is better described in planned surgery like an elective caesarean section, it should be applied to any procedure with a certain likelihood of excessive bleeding, including vaginal delivery or non-elective caesarean section. PBM in obstetrics starts during antenatal care or even preconceptionally.

\section{Haemodynamic changes during pregnancy}

In pregnancy, a range of physiological modifications in the haemodynamic, cardiovascular, and coagulation-fibrinolysis systems occur that are designed by nature to prevent blood loss during delivery. During the first trimester, there is an increase in blood volume [15]. The volume of blood continues to expand rapidly during the 2 nd trimester (30-50\%) before it reaches a stable level in the last 3 months. In parallel, the amount of RBC increases but to a lesser extent (20\%), leading to a relative anaemia due to haemodilution [16], which reaches its maximum by 30-32 weeks of pregnancy. Dilutional decrease of haemoglobin is, therefore, a common physiological process in pregnancy, especially between weeks 28 and 34, when haemoglobin concentrations are lowest. In the first months of pregnancy, the red blood cell mass increases about $18-25 \%$, followed by a drop after childbirth due to peripartal haemorrhage [17-19]. The increase in RBC mass ensures enough oxygen for the increased demands from both mother and foetus. These physiological changes have considerable advantages during pregnancy: The placenta has a better perfusion, the risk of thrombosis decreases, and an adequate blood supply is ensured despite the bleeding that occurs with childbirth [20-22]. Uterine artery blood flow increases during pregnancy (10 times) and reaches $450-750 \mathrm{ml} / \mathrm{min}$ at term [23].

In parallel, there is a substantial increase in clotting capacity with an increase of the coagulation factors I (fibrinogen), VII, VIII, IX, X, XII and von Willebrand factor. Furthermore, there is a decrease of F XIII and a physiologic decrease of protein $\mathrm{S}$, while $\mathrm{F}$ II, V and protein $\mathrm{S}$ do not change [24].

The elevation of plasminogen activator inhibitors 1 and 2 diminishes fibrinolytic activity. Thus, there is an increase of the thromboembolic risk. In summary, haemodynamic and haemostatic changes represent adaptations of nature to the challenges of reproduction and are prerequisites for a successful pregnancy outcome of the mother and her child. Nevertheless, PPH remains a main factor of maternal morbidity and death during childbirth [25].

\section{Causes of postpartum haemorrhage}

Main reasons for severe PPH include uterine atony, retained placenta, placenta praevia, placenta accreta, placental abruption, trauma involving uterine rupture, or lower genital tract trauma and primary coagulopathy [26-28]. The causes of PPH from a clinical perspective are best summarized as the 4 T's: Trauma (of birth canal), Tissue (remaining placenta or placental pieces), Tone (decreased uterine muscular tone: atony), and Thrombin (coagulopathy). Women with previous PPH in the last pregnancy, pre-existing anaemia, prior caesarean section, multiple gestation, uterine fibroma, preeclampsia, obese women, chorioamnionitis, and foetal macrosomia are at increased risk for PPH [29].

However, PPH can occur in every pregnant woman, and most women $(61 \%)$ with PPH do not have a risk factor excluding maternal age and caesarean section [30]. Therefore, we have to consider that all pregnant women are at a considerable risk for PPH. As a consequence, it is also not possible to define those women who have a very low risk for PPH.

\section{Iron deficiency and anaemia in pregnancy}

Preoperative anaemia is often neglected in surgery. The surgical intervention is often performed as planned, and blood is given when considered necessary (part of the standard care) [12]. In obstetrics, there is a unique opportunity to detect iron deficiency and anaemia a long time before a potential blood loss, as well as in each of the following visits of pregnancy care. Therefore, optimal prerequisites exist to implement the first pillar of PBM, and they essentially include the optimization of the red blood cell mass at delivery. In general, anaemia occurs frequently in pregnant women and is mostly associated with iron deficiency. Other causes include haemoglobinopathies [thalassemia, sickle cell anaemia], infections [hook worm, malaria], Vitamin $\mathrm{B}_{12}$ deficiency, or chronic inflammation. In 2011, the percentage of anaemic pregnant women worldwide was $38 \%$, with wide range between different regions: For example, in the Middle East Region, $48.7 \%$ of the pregnant women had anaemia, in Africa $46.3 \%$, and in Europe $25.8 \%$ [31]. In most cases, it is in theory possible to find the reason for anaemia and to treat it correctly during pregnancy, thereby improving the outcome of mother and child.

Due to the lack of clear data reference, haemoglobin values $(\mathrm{Hb})$ during pregnancy are discussed controversially. According to the WHO, during pregnancy, the diagnosis of anaemia is confirmed if $\mathrm{Hb}$ is $<11 \mathrm{~g} / \mathrm{dL}$ [32]. It is of use to have different $\mathrm{Hb}$ reference values in each pregnancy trimester, because it is recognized that between 3 and 6 months of pregnancy $\mathrm{Hb}$-value is reduced by $0.5 \mathrm{~g} / \mathrm{dL}$. 
The primary reason for anaemia in pregnancy is iron deficiency [31]. Iron need increases considerably during pregnancy. Most of the time, iron stores are insufficient to fulfil this increase, which is the consequence of physiological changes (erythrocytes mass $\sim 450 \mathrm{mg}$, placenta $\sim 80 \mathrm{mg}$, bleeding during vaginal delivery birth $\sim 250 \mathrm{mg}$, and foetus $\sim 225 \mathrm{mg}$ ). The iron needs during pregnancy are estimated to $1 \mathrm{~g}$ of additional iron. If the women breastfeeds her child, she will need an extra $1 \mathrm{mg}$ iron per day [33]. Bone marrow biopsies showed that if no extra iron is provided during pregnancy, $80 \%$ of subjects will have exhausted iron reserves at delivery [18]. Of course, the above-mentioned other reasons for anaemia have to be considered and if necessary treated [32-34].

NICE (The English National Institute for Health and Care Excellence) recommends a complete blood count at the beginning of pregnancy and at 28 week gestation, to allow an optimal treatment if anaemia is diagnosed [35]. Other national societies, such as the Swiss Society of Gynaecology and Obstetrics (SSGO), recommend a full blood count and a ferritin value at booking, and thereafter haemoglobin levels every trimester. The reason for low $\mathrm{Hb}$ levels should be clarified and supplementation (iron, $\mathrm{B}_{12}$, etc.) initiated if needed. If anaemia is diagnosed during pregnancy, the following haematological investigations can elucidate the cause of anaemia: a mean red cell volume (MCV) can support the clarification of the causes of anaemia. It can advocate: (a) microcytic anaemia due to iron deficiency or haemoglobinopathy; (b) macrocytic anaemia related to deficiency in vitamin $\mathrm{B}_{12}$ or folate; and (c) normocytic anaemia related to maternal diseases/infections. Of note, in many cases, anaemia in pregnancy is a mixed form of anaemia, such as iron deficiency combined with vitamin $\mathrm{B}_{12}$ deficiency, which may render red blood cell indices less reliable as diagnostic feature. Complementary blood tests are often necessary, and include several haematinic parameters (ferritin, vitamin $\mathrm{B}_{12}$, and folate). In particular circumstances, to exclude haemolysis and make a final classification of anaemia, additional haematological and/or enzymatic parameters should be performed [36-38]. In cases of microcytic anaemia with normal ferritin, investigation of haemoglobinopathies should be undertaken depending on the origin of the patient.

Iron deficiency can, therefore, not be excluded if the MCV is normal. Haemoglobinopathies should always be suspected in case of severe hypochromic microcytic anaemia. Red cell distribution width (RDW) may help to differentiate iron deficiency from other microcytic anaemias, e.g., in case of haemoglobinopathies. Thus, if mean corpuscular haemoglobin is below $26 \mathrm{pg}$, it is important to screen for haemoglobinopathies in case of normal iron stores. Regarding iron stores, serum ferritin seems to be the best and most practical marker. In pregnancy, a serum ferritin concentration $<30 \mu \mathrm{g} / \mathrm{L}$ implies insufficient or empty iron stores and, therefore, an increased risk for developing iron deficiency anaemia. A serum ferritin value $<12 \mu \mathrm{g} / \mathrm{L}$ implies established iron deficiency with empty iron stores at all stages of pregnancy [36-38]. As an acute-phase protein, ferritin increases during inflammation or infectious episodes. Therefore, the measurement of the C-reactive protein (CRP) level at the same time is recommended. A normal serum ferritin value does not exclude iron deficiency in inflammatory situations. Because iron deficiency is very common in pregnancy, serum ferritin screening during first trimester is in several most recent recommendations, for example, by the SSGO [40]. If iron stores are empty in early pregnancy, iron treatment is medically indicated even if the haemoglobin is still normal. As iron demand increases during gestation, untreated iron deficiency will result in incremental anaemia. As outlined above, women suffering from anaemia have an increased risk during PPH or even moderate bleeding.

\section{Prevention and treatment of antepartum iron deficiency and anaemia}

To prevent iron deficiency and iron deficiency anaemia, an alimental iron supplementation of 30-60 mg/day is recommended by the WHO [39] for all pregnant women. There is no recommendation neither in the UK nor in Switzerland for routine iron supplementation in all pregnant women [40, 41]. In countries with an increased prevalence of iron deficiency and anaemia, particularly in low resource countries, routine supplementation of iron seems to be an appropriate strategy. However, iron supplementation may cause undesirable side effects such as gastric pain or constipation in up to $25 \%$ of pregnant women [42]. Therefore, targeted iron treatment in women with iron deficiency anaemia or low iron stores without anaemia is the preferred strategy in populations in which iron deficiency in pregnant women is not extremely high. Hence, it is recommended to check serum ferritin at the beginning of pregnancy and offer oral iron supplementation if serum ferritin is below $30 \mathrm{ng} / \mathrm{ml}$.

In women with mild-to-moderate iron-deficiency anaemia during the first and second trimesters, it is advised to have a daily oral iron substitution (160-200 mg/day of iron) [40]. This is also applicable for iron deficiency without anaemia in early pregnancy (serum ferritin $<30 \mathrm{ng} / \mathrm{mL}$ ) knowing that the iron need will increase during gestation $[40,41,43]$.

Intravenous iron is recommended if there is intolerance to oral iron preparations (gastrointestinal side effects) if $\mathrm{Hb}$ levels do not increase appropriately (less than $1 \mathrm{~g} / \mathrm{dL}$ within 14 days) due to impaired intestinal absorption or poor compliance, in cases with severe, advanced or progressive anaemia $(\mathrm{Hb}<9 \mathrm{~g} / \mathrm{dL})$, or if a rapid anaemia treatment is necessary due to advanced gestational age or in Jehovah's witnesses [32, 40]. The choice of parenteral iron preparation depends on the products availability in different countries. 
Today, iron dextran products are not recommended due to the increased risk of anaphylactic reactions compared to the newer intravenous iron products available (i.e., ferric carboxymaltose, iron sucrose, iron gluconate, etc.) [44]. Based on the available clinical trial data of iv iron treatment in pregnancy [45-48], in Switzerland, the SSGO recommends ferric carboxymaltose use as best treatment choice when parenteral iron use is appropriate [40].

\section{Management of the woman during delivery}

Risk factors for PPH are older age, multiple gestations, preeclampsia, induction of labour, uterine fibroma, polyhydramnios, placenta praevia, and placenta accreta spectrum disorder. The mode of delivery cannot be considered as a predictor for $\mathrm{PPH}$, although caesarean section is associated with a higher average blood loss as compared to vaginal birth. Recent evidence suggests an association between a low pre-partum haemoglobin and an increased risk of $\mathrm{PPH}$. In an observational study with 53 patients with $\mathrm{PPH}$, 21 women had emergency hysterectomy because of serious uterine atony, whereas the remaining 32 women were responsive to standard of care (conservative measures) [49]. Prepartum haemoglobin value was low $(<7 \mathrm{~g} / \mathrm{dL})$ in $81 \%$ of women with hysterectomy and PPH $(n=17 / 21)$ compared to $12.5 \%$ of the non-hysterectomised women. These data showed a strong relationship between anaemia (low Hb values $<10 \mathrm{~g} / \mathrm{dL}$ ) and risk of PPH. The rationale behind this may be decrease myometrial contractility and/or impaired coagulation due to low $\mathrm{Hb}$ levels.

Among the most current guidelines are those of the German, Austrian, and Swiss Societies for Gynaecology and Obstetrics published in 2018 and the RCOG (Royal College of Obstetricians and Gynaecologists) published in 2017 [50, 51]. Risk factors for PPH are often present before birth, according to retrospective studies in about $40 \%$ of women with PPH. In these women, the clinical management during gestation must be modified. One important issue is the facility of birth: Women with a potential of haemorrhage are advised to give birth in a centre, where all required care is onsite.

During delivery, blood loss evaluation is often challenging, but important for clinical management of the patient if bleeding is increased. Typically, blood loss is underestimated by $50 \%$ during vaginal delivery. Blood collecting bags or weighing swaps may help for a more accurate estimation of blood loss. The rapid and appropriate management in case of PPH is crucial to reduce morbidity and, in particular, reduce the need of blood transfusions. Clinicians should be prepared and well trained to use timely appropriate medication, as well as mechanical and surgical interventions to stop PPH. The key factor is to perform a rapid but thorough examination to identify the cause of haemorrhage (4TS) and treat it accordingly. The therapy of PPH after vaginal birth or caesarean section depends on the clinical situation and the cause of PPH (4 T's: Trauma, Tissue, Tone, Thrombin, see above) and consists of different therapeutic measures: Suturing of tissue laceration in birth canal or uterine rupture, surgical removal of placental tissue, uterotonic medications, and administration of Pro-coagulants. If bleeding persists, further measures include insertion of a Balloon-tamponade of the uterus, surgical intervention such as uterine compression sutures (B-Lynch, Hayman technique, or others [52]) or uterine vessel mass ligation. In haemodynamically stable patients, emergent transfer to interventional radiology department and uterine artery embolization may be an effective and often successful intervention [53]. Finally, hysterectomy might become necessary as ultima ratio if other measures were unsuccessful.

\section{Prevention of PPH}

To minimise the risk of PPH, Cochrane reviews [54-56] have shown that the proactive management of the third stage of labour which consists of prophylactic administration of uterotonics such as oxytocine, carbetocin, or ergometrine is successful in preventing PPH. The main component of the package is the use of oxytocin or carbetocin, as controlled cord traction adds only very little [57]. Early cord clamping limits the blood volume to the newborn and may lead to iron deficiency and anaemia in preterm born babies [58]. It has been shown that delaying umbilical cord clamping (minimum $1 \mathrm{~min}$.) have an extended benefit (up to infancy) for the new-born [59]. Therefore, systematic early clamping of the umbilical cord is not advised anymore, except in emergency cases such as severe foetal distress or placental abruption.

\section{Fluid management}

Several physiological changes occur during pregnancy. In the first months, the body of the pregnant woman holds off about 500 up to $900 \mathrm{mEq}$ of sodium [60-62], which increases the body water volume by 6-8 L. Development of resistance to angiotensin II occurs in parallel to an upregulation of the renin-angiotensin system. This leads to a broad rise of 4-7 $\mathrm{L}$ in the volume of extracellular water and a reduction of sodium and water elimination to keep a physiologic blood pressure [63, 64]. Stroke volume and heart rate increase. Cardiac output rises rapidly at the beginning of the 5th week of gestation (first trimester) and continues until the 32nd week. It reaches the maximum around the 6th month of pregnancy, having reached $\sim 130-150 \%$ of the values of non-pregnant women. After birth, cardiac output decreases and turns back to normal levels only at 24 week postpartum. Colloid osmotic pressure (COP) may decrease from $25 \mathrm{mmHg}$ to 
18-20 $\mathrm{mmHg}$ and cause oedema. All the factors mentioned above should be kept in mind and taken into consideration for the fluid management of complicated obstetric patients.

During severe PPH, decreased cardiac output, hypotension, and vasoconstriction may cause a decrease in endorgan perfusion of vital organs, including kidneys, heart, and brain [65]. Fluid management is a crucial component of PPH treatment to maintain adequate tissue perfusion. Not only blood loss is difficult to estimate, the same is true for volume status of the patient. Due to the physiological increase in blood volume and cardiac output, the parturient may present with cardiovascular stability despite significant blood loss. Shock index (heart rate divided by systolic blood pressure) above 1 is considered a helpful marker to identify relevant hypovolaemia [66]. Maternal lactate is also used by anaesthetists to monitor tissue hypo perfusion in case of significant blood loss. It is important to appropriately warm the infused volume to avoid hypothermia, which has a negative impact on coagulation, oxygenation acidosis [67]. There is no consensus on the choice of crystalloid or colloidal infusion [68] and there is no standard for the appropriate volume of resuscitation fluids [69-71].

\section{Treatment of PPH}

Uterine atony is the most frequent reason for PPH. Therefore, methods to stimulate contractions of the myometrium should be used. According to Mavrides et al. (a Cochrane review), the management can start at the following sequence $[50,72]$ :

1. Uterine fundus palpation and rubbing for stimulation of contractions.

2. Bladder emptying (leave the Foley catheter in place). Ensure a complete placenta or uterine vacuity if doubt.

3. Intravenous injection (i.v.) of Oxytocin 5 IU (additional dose might be needed).

4. Parenteral administration of Oxytocin (40 IU in $500 \mathrm{~mL}$ isotonic solution at $125 \mathrm{ml} / \mathrm{h}$ ) except if there is a need of fluid limitation.

5. If the previous interventions did not lead to appropriate response, sulprostol should be administered by controlled infusion.

6. In case of non-availability of sulprostol, 800 micrograms of misoprostol can be used rectally or other uterotonics including prostaglandin F2alpha or ergometrin may be administered.

Expert consensus supports the use of these methods, even though no evidence-based trial was published [73].

\section{Tranexamic acid}

Antifibrinolytics such as aminomethylbenzoic acid, aprotinin, aminocaproic acid, and tranexamic acid diminish bleeding. They act by the inhibition of fibrin clots breakdown $[74,75]$. It has been shown in surgery that tranexamic acid can reduce bleeding and consequently reduce by $1 / 3$ the need for RBC transfusion [76]. Large clinical trials have shown that early administration of tranexamic acid reduced mortality in trauma patients. Similarly, a large multicentre RCT in women with PPH has shown reduction of morbidity as well as mortality. Importantly, the effect was best if tranexamic acid was administered within the three first hours after the onset of the haemorrhage [77-79]. It is of note that in these patients, most severe bleeding and death occurs within $12 \mathrm{~h}$ after haemorrhage start. In PPH, death peaked $2-3 \mathrm{~h}$ after delivery. The important WOMAN trial has shown that there is an improvement of survival with the use of tranexamic acid [78]; however, it should be used rapidly otherwise the benefit reduces by $10 \%$ per $15 \mathrm{~min}$ delay up to no benefit reported after $3 \mathrm{~h}$ [80]. Of note, the WOMAN trial has been subject to criticism regarding the issues of the included patient population and regarding the number needed to treat. Patients with increased blood loss during vaginal birth or caesarean section should receive antifibrinolytic drugs as soon as possible for the reasons mentioned above. While bleeding, the first coagulation factor to drop to critically low levels is fibrinogen. Therefore, early inhibition of fibrinolysis is reasonable and tranexamic acid must be given before substitution of fibrinogen. Early administration of tranexamic acid is, meanwhile, recommended as the first line of treatment for women with increased blood loss during birth.

In women who were treated prophylactically with tranexamic acid ( 1 or $0.5 \mathrm{~g}$ i.v.) plus the usual uterotonics after vaginal delivery or caesarean section, bleeding beyond 400 or $500 \mathrm{ml}$ was less frequent [81]. A French randomised controlled study comparing $1 \mathrm{~g}$ of prophylactic tranexamic acid with placebo showed an effect on the incidence of $\mathrm{PPH}$ [82]; however, more data are needed before prophylactic tranexamic acid can be recommended [50].

\section{Red blood cell transfusion}

During PPH, it is of high importance to make the difference between active bleeding and non-active bleeding regarding the indication for RBC transfusion. In principle, during active bleeding in the acute phase of PPH, the dynamic of the clinical situation can be extremely high, and quick RBC transfusions often save the life of the patient. Criteria for transfusion mainly include estimation of blood loss, haemodynamic situation and tissue oxygenation level (lactate), haemoglobin $(\mathrm{Hb}) /$ haematocrit $(\mathrm{Ht})$, and prediction of severity 
of PPH (e.g., by measuring fibrinogen). Measuring just $\mathrm{Hb} /$ $\mathrm{Ht}$ is not the most reliable way to monitor the progress of the clinical situation. Assessment can be inaccurate leading to a delay of blood transfusion; therefore, further clinical criteria need to be taken into account for an optimal monitoring of the situation, specifically haemodynamic criteria. In haemorrhage and resuscitation, the European Society of Anaesthesiology advocates that $\mathrm{Hb} / \mathrm{Ht}$ along with base deficit and serum lactate should be measured repeatedly for tissue perfusion and oxygenation evaluation [83]. It should, however, be kept in mind that physiological metabolic compensation of respiratory alkalosis is common in pregnancy, and therefore, a base deficit of up to -3 is physiological. Base deficit with a concomitant increase of serum lactate is a sign of hypoperfusion, usually due to hypovolemia. Correction of hypovolemia with crystalloid fluids might unmask anaemia.

In the later phase of PPH, when bleeding is stopped, active (internal) blood loss is excluded and the haemodynamic stability and compensation of the patient is confirmed, the indication for blood transfusion should be more restrictive with no fixed criteria for RBC transfusions [84, 85]. Hb below $6 \mathrm{~g} / \mathrm{dL}$ does usually require a RBC transfusion, while this is rarely the case in a haemodynamically stable situation with an $\mathrm{Hb}$ of $8 \mathrm{~g} / \mathrm{dL}$ or above. Between 6 and $8 \mathrm{~g} / \mathrm{dL}$, transfusion indication should be more restrictive, depending on the clinical situation and on patient's symptoms. Often, red blood cell transfusion can be avoided, and instead, intravenous iron treatment can be initiated 8if iron stores have been short) for rapid recovery of $\mathrm{Hb}$ levels and alleviation of clinical symptoms.

\section{Fibrinogen concentrate}

Fibrinogen is an acute phase protein and is essential for effective haemostasis. It has been shown that fibrinogen levels measured during PPH correspond well to the severity of $\mathrm{PPH}$, although it is unclear if low fibrinogen values contribute to the pathogenesis of PPH or are a secondary phenomenon of blood loss [86-88]. Several studies [89-96] have suggested that fibrinogen might be useful in normalizing standard laboratory tests in PPH associated with hypofibrinogenaemia. Much of the evidence supporting a benefit of fibrinogen concentrate for PPH is based on case series, retrospective register investigations, or uncontrolled, nonrandomised studies [97]. Despite this, early administration of fibrinogen has already been included in most guidelines [98]. For example, the European Society of Anaesthesiology recommends to provide fibrinogen if the levels are $<2 \mathrm{~g} /$ $\mathrm{dL}$ [83], this is also the case for several obstetric societies like the RCOG [50]. Fibrinogen concentrate is associated with reduced bleeding and a decreased need for transfusions in PPH. Fibrinogen concentrate should be given in severe PPH, particularly if fibrinogen levels are low. Because measurement of fibrinogen levels is time consuming and, therefore, impractical in ongoing PPH, bedside tests, such as thromboelastometry, are recommended. This may enable a rapid correction of coagulopathy due to consumption and dilution [99].

\section{Transfusion of fresh frozen plasma}

Fresh-frozen plasma (FFP) has a limited clotting capacity and is inferior to fibringogen concentrate for the treatment of hypofibrinogenaemia. As a colloidal infusion, FFP is given for volume resuscitation in situations with severe hypovolemia and concomitant coagulopathy. Thawing FFP is time-consuming, and therefore, timely organisation of FFP is recommended [50].

\section{Recombinant activated human factor VII (rhFVIla)}

Recombinant human factor VIIa (rhFVIIa) is a tissue factor-activated prohaemostatic agent. Even in severe PPH, the systematic use of rhFVVa has not been recommended [49]. Efficacy of rhVIIa has been shown in non-randomised studies in severe PPH. The risk of thromboembolic complications has not been systematically investigated. To be effective, rhVIIa requires correction of hypothermia, acidosis, fibrinogen levels, and anaemia [100]. If haemorrhage could not be controlled by other measures, rhFVIIa could lower the need of second-line therapies [101]. In a prospective cohort study with 22 patients with severe PPH rhVIIa contributed to the control of PPH and hysterectomy was avoided [102]. In life-threatening PPH, rFVIIa administration might be used. However, this should not replace or postpone vital interventions. It is of note that patients should be monitored to detect thromboembolism, especially if rhVIIa is given in the combination with tranexamic acid.

\section{Surgical/interventional strategies as second-line treatments for PPH}

\section{Uterine balloon tamponade}

It is possible to manage the majority of severe PPH situations when blood loss is rapidly minimised and stopped using appropriate methods, for example, with uterotonics and other interventions. However, these therapies are not always effective in stopping severe bleeding. Therefore, to manage severe PPH and reduce morbidity and mortality, it is necessary to combine several methods including second-line treatments which can be applied even in low-resource structures. In this case, uterine balloon tamponade can be useful. It is a relatively simple and effective approach. A balloon device (Bakri-balloon) is introduced in the uterus and filled with fluid to apply pressure on the uterine walls and allow 
haemorrhage discontinuation. When this method works to stop bleeding, it is unlikely that the patient needs surgery (in particular, laparotomy after vaginal birth) and RBC transfusions. In the situation, where balloon tamponade is not fully effective to stop severe bleeding, it can help to stabilise the situation until the patient is transferred to a structure which has more treatment options (bridging method). Balloon tamponade works quite fast (5-10 min.) after start of use. Balloon tamponade can help in unmanageable PPH or in areas/structures, where efficient methods for PPH are unavailable. Therefore, it has been recommended in several guidelines (The WHO, the American College of Obstetricians and Gynaecologists, the International Federation of Gynaecology and Obstetrics, the RCOG, and the International Confederation of Midwives) [103-105].

\section{Embolization}

Arterial embolization after PPH can be successful in arresting the bleeding [106]. Prerequisites for embolization are availability and logistics of interventional radiology, and haemodynamic stability of the patient. In situations, where an interventional radiologist or the logistics to perform arterial occlusion or embolization are not available, uterine balloon tamponade should be considered as first-line treatment. Balloon tamponade can also can be used to bridge the time until embolization. Longitudinal trials in patients who underwent arterial embolization to manage PPH showed that this method does not affect the following menstruation cycles or fertility [53]. If artery ligation failed, selective arterial occlusion might be considered [107]. Embolization seems to work to manage severe postpartum blood loss and to conserve fertility especially in life-threatening situations.

\section{Uterine compression sutures}

When the relatively non-invasive treatment of Balloon tamponade does not stop PPH, the next step is the use of more invasive treatments requiring laparotomy. If no active bleeding vessel is identified, uterine compression sutures can be applied. In 1997, the B-Lynch uterine compression suture was introduced and became the most widely performed suture. Subsequently, several other uterine compression sutures were described, such as Hayman, Cho, Pereira, Ouahba, or Hackethal suture. Up to date, randomised trials comparing the compression sutures to other procedures are missing. The average rate of haemostasis is $97 \%$ with a range from $76 \%$ to $100 \%$ [108]. The success rate is higher if compression suture is performed within $1 \mathrm{~h}$ after delivery. The risk for hysterectomy is increased by fourfolds if there is a 2-6 h delay (after delivery) of uterine compression suture [109].
Ligature of the uterine and utero-ovarian arteries is further surgical interventions and can decrease uterine bleeding by reducing perfusion pressure in the myometrium. It does not harm the uterus and does not appear to impact reproductive function [110]. Iliac artery ligation remains challenging even for an experienced pelvic surgeon [111]. Therefore, arterial embolization, uterine artery ligation, and uterine compression sutures largely replaced this procedure.

\section{Cell salvage}

Cell salvage is the process of washing and returning intraoperatively collected RBC to the patient. Cell salvage is frequently used in non-obstetric surgeries with anticipated major blood loss. In obstetrics, cell salvage is recommended in individual situations with anticipated high blood loss, such as placenta accreta spectrum disorder, while it is not recommended as a routine procedure for caesarean delivery [112]. Cell salvage is frequently acceptable to Jehova's witnesses, although individual consent has to be sought.

\section{Postpartum hysterectomy}

If all treatments mentioned above fail, hysterectomy (HE) is the last resort of PPH treatment. As such, it is also associated with further blood loss. Therefore, the decision for HE should not be delayed too much and decision taken too late when there is haemodynamic instability, severe coagulation deficiency, and further signs of decompensation such as tissue hypoxia or hyperthermia. On the other hand, hysterectomy leads to definitive loss of fertility, reason why it should be used only as last resort treatment. An experienced clinician should decide if and when HE is necessary. The request of a second opinion is advised when possible [113]. Postpartum HE requires an experienced gynaecologic surgeon. It is usually performed as supracervical HE to shorten operation time and decrease additional blood-loss. Only in placenta previa and/or morbidly adherent placenta, it is often necessary to perform a total HE including the cervix.

\section{Active and non-active bleeding in delivery and postpartum haemorrhage}

In general, blood transfusions hold risks. Furthermore, for religious reasons, some women such Jehovah's witnessesdecline RBC. For these reasons, there must be a clear indication for RBC transfusion, such as risk of ongoing haemorrhage with severe anaemia or cardiac decompensation [114]. A recent paper [114] identified only one small randomised controlled trial with 72 pregnant women investigating the role of proactive (prophylactic) or reactive (restrictive), administration of blood. The conclusion of the authors was not in favour of prophylactic blood transfusion [115]. There 
are missing studies of the consequences of blood transfusion on the mortality of the mothers or the new-borns. Thus, any endorsement from experts is based on the clinical experience but not evidence based [39]. Severe anaemia during pregnancy was linked to low foetal oxygenation, resulting in foetal morbidity and mortality, and reduction of amniotic fluid volume $[116,117]$. In these situations, foetal surveillance and blood transfusion in the mother need to be taken into consideration. [35, 43]. In the case of severe anaemia in pregnancy (e.g., $\mathrm{Hb}<7 \mathrm{~g} / \mathrm{dL}$ ), the patient should be addressed to a specialized foeto-maternal medicine care centre. If there is no active bleeding but transfusion deems to be necessary, the minimum amount of blood should be transfused (single-unit). Subsequently, clinical and laboratory evaluation should be performed to reassess the additional need of blood transfusion. Iron stores cannot be replenished by a single RBC concentrate ( $240 \mathrm{mg}$ iron); thus, the additional administration of parenteral iron is recommended. Importantly, restrictive recommendations for transfusion apply only for patients with stable circulation and no active bleeding. In women with active bleeding, transfusions may not be avoidable in many patients and can safe life. Nevertheless, some women-also if necessary-do not accept blood products, for example Jehovah`s witnesses. In those women, PBM improves both short- and long-term outcomes, due to the synergies between preoperative haematological values optimisation, good volume management, and precise methods of surgery [118], but when these steps fail with active bleeding, the obstetrician has to choose expedite technique to fix the situation i.g. hysterectomy.

\section{Management of women postpartum}

\section{Evaluation of postpartum haemoglobin}

To determine postpartum haemoglobin might have a great impact on the mother's well-being. Researchers from Spain found an association between ferritin concentration during the immediate postpartum period and postpartum depression [119]. In women with postpartum depression (PPD), the ferritin concentration was lower and more women had depleted iron stores than those without depression. On average, more patients in the PPD arm compared to the non-PPD arm had depleted iron stores without marginal iron deficiency. The problem with these studies is that ferritin levels postpartum are often erroneously high due to an inflammation in particular after caesarean section and PPH, as ferritin is increased in the acute phase of inflammation. We, therefore, suggest omitting ferritin-level measurements in the postpartum period and instead measure $\mathrm{Hb}$, ideally around $48 \mathrm{~h}$ after birth as this usually represents the $\mathrm{Hb}$ nadir. Nevertheless, there are increased iron needs during pregnancy and postpartum both directly through to the demands of the developing foetus, and indirectly through breastfeeding depletes iron stores. Iron deficiency in postpartum women may alter neurotransmitter and myelin metabolism and thus increase the risk of PPD in susceptible women. Recently, a Danish study showed a correlation between iron deficiency anaemia and high score on the EPDS (Edinburgh Postpartum Depression Scale). Half of women involved in PPD are undiagnosed and untreated. Appropriate iron treatment may, therefore, decrease the incidence of PPD in postpartum iron deficiency.

\section{Postpartum anaemia}

Iron deficiency anaemia is very frequent in postpartum and is usually due to postpartum blood loss. It is considered as an important health concern. The SSGO defines postpartum anaemia as an $\mathrm{Hb}<12 \mathrm{~g} / \mathrm{dL}$ within $\sim 48 \mathrm{~h}$ after delivery (the nadir) [40]. Others define postpartum anaemia as an $\mathrm{Hb}<11 \mathrm{~g} / \mathrm{dL} 1$ week postpartum or $\mathrm{Hb}<12 \mathrm{~g} /$ dL 8 week postpartum [32, 120, 121]. Many women suffer from postpartum anaemia. From 43.807 German women who delivered in 1993-2008, 22\% had postpartum anaemia with an $\mathrm{Hb}<10 \mathrm{~g} / \mathrm{dL}$ after $24-48 \mathrm{~h}$ from birth [122]. In Denmark, $14 \%$ of women who received iron suffered from postpartum anaemia 1 week after vaginal birth in comparison with a prevalence of $24 \%$ in those who did not receive iron [123]. According to the SSGO, at least onethird up to half of postpartum woman in Switzerland are anaemic [40]. Often, postpartum anaemia is due to prepartum iron-deficiency with or without anaemia and/or acute blood loss during delivery [122, 124, 125]. There are several factors, which could increase the risk of PPH [i.g. ethnicity, inflammation (post-caesarean section), vitamin B12 or folic acid deficiency, multiparity, haemoglobinopathies, and infections] [122, 126-128]. Both postpartum anaemia and iron deficiency can induce several consequences such as reduction of physical and cognitive capacity (fatigue, dyspnoea, etc.), higher susceptibility to infections, disability of breast feeding, higher risk of postpartum depression [122], and compromised ability of bonding to the baby [129]. Postpartum anaemia may also increase health-care costs [114]. Thus, the reasons that could lead to postpartum anaemia should be foreseen and corrected in the best way. The postpartum $\mathrm{Hb}$ concentration should be allowed to stabilise after delivery for at least $48 \mathrm{~h}$ before a reliable diagnosis of postpartum anaemia is performed. To have a reliable $\mathrm{Hb}$ value, one should wait 1 week after delivery [121]. However, if anaemia or iron deficiency is misdiagnosed in immediate postpartum, an estimation of serum ferritin together with a complete blood count (CBC) 4-8 week postpartum is a good alternative [128]. To have an unaltered serum ferritin level, inflammation should be excluded by measuring the CRP [38]. 


\section{Prevention and treatment of postpartum anaemia}

Prepartum iron deficiency with or without anaemia is closely related to anaemia after birth. As postpartum anaemia can be severe and have durable negative consequences of the mother and her child, postpartum anaemia should be avoided by filling up iron stores during (or even before) pregnancy [130]. According to available studies, oral iron supplementation during pregnancy can lower the risk of anaemia during pregnancy and postpartum [131-133]. In case of asymptomatic mild anaemia, the woman should be treated with oral iron (80-200 mg/day for a minimal duration of 3 months) [40, 130]. The patient should be informed on the correct way of oral iron intake to avoid food interactions and have an optimal absorption [41].

Currently available information suggests that intravenous iron in the postpartum period is beneficial and more efficient than oral iron, particularly in women with moderate or severe anaemia $[134,135]$. In the systematic review by Sultan et al., Hb at 6 week postpartum were almost $10 \mathrm{~g} / \mathrm{dL}$ higher in women with postpartum anaemia who received intravenous iron compared to oral iron. Given the reassuring safety profile of intravenous iron, the weaker $\mathrm{Hb}$ response and higher risk of gastrointestinal side-effects with oral iron use, i.v. iron can be considered as a viable treatment option for postpartum iron deficiency anaemia [135].

After birth, treatment of iron deficiency anaemia includes the recommendations according to the SSGO [40]:

- Hb from $9.5 \mathrm{~g} / \mathrm{dL}$ to $12 \mathrm{~g} / \mathrm{dL}$ : Oral iron therapy. If oral iron medication is badly tolerated due to gastrointestinal side effects, intravenous iron treatment should be administered.

- $\mathrm{Hb}<9.5 \mathrm{~g} / \mathrm{dL}$ : intravenous iron therapy (as first line therapy, ferric carboxymaltose as first-choice product).

Basis of this recommendation are randomised studies showing a more rapid increase of haemoglobin after intravenous iron as compared to oral iron $[45,46]$. In particular, in the postpartum period, a rapid recovery is essential for successful breastfeeding and that the mother is able to cope with all the challenges of care for the neonate.

In case of caesarean section or postpartal inflammation, oral iron may not be efficiently absorbed because of the increased Hepcidin level (iron regulator) [136]. Therefore, in such situations (women with inflammation, severe anaemia or refusing RBC transfusion like Jehovah's witnesses) parenteral iron should be considered as first-line treatment.

The decision to administer RBC transfusion should be considered according to postpartum $\mathrm{Hb}$ value as well as clinical symptoms. It can be appropriate when $\mathrm{Hb}$ value is $<6 \mathrm{~g} / \mathrm{dL}$, or between 7 and $9 \mathrm{~g} / \mathrm{dL}$ if symptoms of anaemia are severe. As a principle, in postpartum women without active bleeding, transfusion should be restrictive and include administration of only one packed red blood cell, followed by $\mathrm{Hb}$ measurement and clinical evaluation to decide if more is necessary. When $\mathrm{Hb}$ value is $>9 \mathrm{~g} / \mathrm{dL}$, blood transfusion is barely needed $[35,40,43]$.

\section{Conclusion}

All pregnant women have a significant risk for PPH. Risk factors do exist; however, $60 \%$ of women with PPH do not have a risk factor. Patient blood management in obstetrics must, therefore, not only be focused on women with identified risk factor of PPH, but on all pregnant women [30].

PBM in obstetrics is based on 3 main pillars:

1. Measures during pregnancy.

Identification of anaemia and its cause, treatment of anaemia, early treatment of iron deficiency, optimization of red blood cell mass in view of delivery.

Identify patients with a very high risk for PPH (for example placenta praevia, placenta increta, large uterine fibroma, etc.), to appropriately plan logistics, management of delivery and PBM. They should preferably deliver in a tertiary care centre.

2. Measures during delivery.

Use pre-emptive administration of uterotonics after delivery to prevent PPH.

Minimize blood loss during delivery using appropriate surgical technique in caesarean section.

In case of PPH, use appropriate modern measures to minimize blood loss, including balloon tamponade, tranexamic acid and fibrinogen administration, recombinant activated factor VII administration, uterine compression sutures, uterine artery embolization, and cell salvage.

3. Measures during the postpartum phase.

Manage postpartum anaemia by appropriate iron administration. Optimise the patient's physiological response to anaemia, treat infections and maximize oxygen delivery to minimize transfusions. Use differential management in active bleeding and non-active bleeding phase of PPH: During active and heavy bleeding, blood transfusions are often necessary, sometimes massive transfusions, to save the life of the patient. However, during non-active bleeding phase unnecessary red blood cell transfusions must be avoided, and a restrictive use of blood transfusion should be applied. In that case, i.v. iron infusion seems a better option than oral supplementation to resolve postpartum anaemia.

These three main pillars should be kept in mind by all professionals taking care of pregnant women, including 
obstetricians, general practitioners, midwifes, and anaesthesiologists. PBM should be more thoroughly introduced in clinical guidance for pregnancy care and $\mathrm{PPH}$ of national and international obstetrical societies.

Acknowledgements The authors want to thank Dr. Neige Morin for her tremendous work and support in manuscript editing and formatting.

Author contribution DS, IH, YV, DB, and RH conceptualized the review and selected the review methodology. DS and IH wrote the manuscript. DS, IH, YV, TG, and CB contributed substantially to the literature analysis and interpretation. DS, IH, YV, TG, CB, GA, RH, $\mathrm{DB}$, and BMT performed a substantial revision and correction of the paper for critical medical content. All authors (Swiss Working Group for PBM in Obstetrics) have read and approved the final version of the paper.

Funding Vifor Pharma provided an unrestricted research grant to cover travel expenses for the panel meeting. Vifor Pharma had no impact on the discussions, their outcome and on the manuscript content.

\section{Compliance with ethical standards}

Conflict of interest GA, DB, and BMT declare that they have no competing interests. YV declared, one time lecture fees from Vifor Pharma. TG declared lecture fees from CSL Behring. RH declared one time consulting fees from Vifor Pharma. $\mathrm{CB}$ and $\mathrm{IH}$ are consulting expert for Vifor International in the field of obstetrics and/or women's Health. DS declared lecture and consulting fees, and unrestricted grant for scientific study from Vifor Pharma.

Ethical approval This article does not contain any studies with human participants or animals performed by any of the authors.

Open Access This article is distributed under the terms of the Creative Commons Attribution 4.0 International License (http://creativecommons.org/licenses/by/4.0/), which permits unrestricted use, distribution, and reproduction in any medium, provided you give appropriate credit to the original author(s) and the source, provide a link to the Creative Commons license, and indicate if changes were made.

\section{References}

1. Mehra T, Seifert B, Bravo-Reiter S, Wanner G, Dutkowski P, Holubec T, Moos RM, Volbracht J, Manz MG, Spahn DR (2015) Implementation of a patient blood management monitoring and feedback program significantly reduces transfusions and costs. Transfusion 55(12):2807-2815. https://doi.org/10.1111/trf.13260

2. Gross I, Seifert B, Hofmann A, Spahn DR (2015) Patient blood management in cardiac surgery results in fewer transfusions and better outcome. Transfusion 55(5):1075-1081. https://doi. org/10.1111/trf.12946

3. Goodnough LT, Maggio P, Hadhazy E, Shieh L, HernandezBoussard T, Khari P, Shah N (2014) Restrictive blood transfusion practices are associated with improved patient outcomes. Transfusion 54(10 Pt 2):2753-2759. https://doi.org/10.1111/ trf. 12723

4. Keding V, Zacharowski K, Bechstein WO, Meybohm P, Schnitzbauer AA (2018) Patient Blood Management improves outcome in oncologic surgery. World J Surg Oncol 16(1):159. https://doi. org/10.1186/s12957-018-1456-9

5. Meybohm P, Richards T, Isbister J, Hofmann A, Shander A, Goodnough LT, Munoz M, Gombotz H, Weber CF, Choorapoikayil S, Spahn DR, Zacharowski K (2017) Patient Blood Management Bundles to Facilitate Implementation. Transfus Med Rev 31(1):62-71. https://doi.org/10.1016/j.tmrv.2016.05.012

6. Theusinger OM, Kind SL, Seifert B, Borgeat L, Gerber C, Spahn DR (2014) Patient blood management in orthopaedic surgery: a four-year follow-up of transfusion requirements and blood loss from 2008 to 2011 at the Balgrist University Hospital in Zurich, Switzerland. Blood Transfus 12(2):195-203. https://doi. org/10.2450/2014.0306-13

7. Leahy MF, Hofmann A, Towler S, Trentino KM, Burrows SA, Swain SG, Hamdorf J, Gallagher T, Koay A, Geelhoed GC, Farmer SL (2017) Improved outcomes and reduced costs associated with a health-system-wide patient blood management program: a retrospective observational study in four major adult tertiary-care hospitals. Transfusion 57(6):1347-1358. https://doi. org/10.1111/trf.14006

8. Roubinian NH, Escobar GJ, Liu V, Swain BE, Gardner MN, Kipnis P, Triulzi DJ, Gottschall JL, Wu Y, Carson JL, Kleinman SH, Murphy EL (2014) Trends in red blood cell transfusion and 30-day mortality among hospitalized patients. Transfusion 54(10 Pt 2):2678-2686. https://doi.org/10.1111/trf.12825

9. Trentino KM, Farmer SL, Swain SG, Burrows SA, Hofmann A, Ienco R, Pavey W, Daly FF, Van Niekerk A, Webb SA, Towler S, Leahy MF (2015) Increased hospital costs associated with red blood cell transfusion. Transfusion 55(5):1082-1089. https://doi. org/10.1111/trf. 12958

10. Althoff FC, Neb H, Herrmann E, Trentino KM, Vernich L, Fullenbach C, Freedman J, Waters JH, Farmer S, Leahy MF, Zacharowski K, Meybohm P, Choorapoikayil S (2018) Multimodal patient blood management program based on a three-pillar strategy: a systematic review and meta-analysis. Ann Surg. https:// doi.org/10.1097/sla.0000000000003095

11. WHO (2010) WHA63.12 availability, safety and quality of blood products. WHA resolution the sixty-third world health assembly. WHO, Geneva

12. Munoz M, Gomez-Ramirez S, Kozek-Langeneker S, Shander A, Richards T, Pavia J, Kehlet H, Acheson AG, Evans C, Raobaikady R, Javidroozi M, Auerbach M (2015) 'Fit to fly': overcoming barriers to preoperative haemoglobin optimization in surgical patients. Br J Anaesth 115(1):15-24. https://doi.org/10.1093/bja/ aev 165

13. Hofmeyr GJ, Qureshi Z (2016) Preventing deaths due to haemorrhage. Best Pract Res Clin Obstet Gynaecol 36:68-82. https://doi. org/10.1016/j.bpobgyn.2016.05.004

14. Shaylor R, Weiniger CF, Austin N, Tzabazis A, Shander A, Goodnough LT, Butwick AJ (2017) National and international guidelines for patient blood management in obstetrics: a qualitative review. Anesth Analg 124(1):216-232. https://doi. org/10.1213/ane.0000000000001473

15. Ickx BE (2010) Fluid and blood transfusion management in obstetrics. Eur J Anaesthesiol 27(12):1031-1035. https://doi. org/10.1097/EJA.0b013e32833c30e3

16. Bernstein IM, Ziegler W, Badger GJ (2001) Plasma volume expansion in early pregnancy. Obstet Gynecol 97(5 Pt 1):669-672

17. Hytten F (1985) Blood volume changes in normal pregnancy. Clin Haematol 14(3):601-612

18. Harstad TW, Mason RA, Cox SM (1992) Serum erythropoietin quantitation in pregnancy using an enzyme-linked immunoassay. Am J Perinatol 9(4):233-235. https://doi. org/10.1055/s-2007-994778 
19. De Leeuw NK, Lowenstein L, Tucker EC, Dayal S (1968) Correlation of red cell loss at delivery with changes in red cell mass. Am J Obstet Gynecol 100(8):1092-1101

20. Cavill I (1995) Iron and erythropoiesis in normal subjects and in pregnancy. J Perinat Med 23(1-2):47-50

21. Koller O (1982) The clinical significance of hemodilution during pregnancy. Obstet Gynecol Surv 37(11):649-652

22. Clapp JF 3rd, Little KD, Widness JA (2003) Effect of maternal exercise and fetoplacental growth rate on serum erythropoietin concentrations. Am J Obstet Gynecol 188(4):1021-1025

23. Flo K, Wilsgaard T, Vartun A, Acharya G (2010) A longitudinal study of the relationship between maternal cardiac output measured by impedance cardiography and uterine artery blood flow in the second half of pregnancy. BJOG 117(7):837-844. https://doi.org/10.1111/j.1471-0528.2010.02548.x

24. Katz D, Beilin Y (2015) Disorders of coagulation in pregnancy. Br J Anaesth. https://doi.org/10.1093/bja/aev374

25. Atrash HK, Koonin LM, Lawson HW, Franks AL, Smith JC (1990) Maternal mortality in the United States, 1979-1986. Obstet Gynecol 76(6):1055-1060

26. Tsu VD, Langer A, Aldrich T (2004) Postpartum hemorrhage in developing countries: is the public health community using the right tools? Int J Gynaecol Obstet 85(Suppl 1):S42-S51. https://doi.org/10.1016/j.ijgo.2004.02.009

27. Doumouchtsis SK, Papageorghiou AT, Arulkumaran S (2007) Systematic review of conservative management of postpartum hemorrhage: what to do when medical treatment fails. Obstet Gynecol Surv 62(8):540-547. https://doi.org/10.1097/01. ogx.0000271137.81361.93

28. Chichakli LO, Atrash HK, MacKay AP, Musani AS, Berg CJ (1999) Pregnancy-related mortality in the United States due to hemorrhage: 1979-1992. Obstet Gynecol 94(5 Pt 1):721-725

29. Cohen WR (2006) Hemorrhagic shock in obstetrics. J Perinat Med 34(4):263-271. https://doi.org/10.1515/jpm.2006.051

30. Bateman BT, Berman MF, Riley LE, Leffert LR (2010) The epidemiology of postpartum hemorrhage in a large, nationwide sample of deliveries. Anesth Analg 110(5):1368-1373. https:// doi.org/10.1213/ANE.0b013e3181d74898

31. Stevens GA, Finucane MM, De-Regil LM, Paciorek CJ, Flaxman SR, Branca F, Pena-Rosas JP, Bhutta ZA, Ezzati M (2013) Global, regional, and national trends in haemoglobin concentration and prevalence of total and severe anaemia in children and pregnant and non-pregnant women for 1995-2011: a systematic analysis of population-representative data. Lancet Glob Health 1(1):e16-e25. https://doi.org/10.1016/s2214 $-109 x(13) 70001-9$

32. WHO (2009) Haemoglobin concentrations for the diagnosis of anaemia and assessment of severity. Vitamin and Mineral Nutrition Information System. WHO, Geneva

33. Bothwell TH (2000) Iron requirements in pregnancy and strategies to meet them. Am J Clin Nutr 72(1 Suppl):257s-264s. https ://doi.org/10.1093/ajen/72.1.257S

34. Kassebaum NJ, Jasrasaria R, Naghavi M, Wulf SK, Johns N, Lozano R, Regan M, Weatherall D, Chou DP, Eisele TP, Flaxman SR, Pullan RL, Brooker SJ, Murray CJ (2014) A systematic analysis of global anemia burden from 1990 to 2010. Blood 123(5):615-624. https://doi.org/10.1182/blood-2013-06-508325

35. NICE (2008) Antenatal care for uncomplicated pregnancies. NICE Guideline, London

36. Hallberg L, Bengtsson C, Lapidus L, Lindstedt G, Lundberg PA, Hulten L (1993) Screening for iron deficiency: an analysis based on bone-marrow examinations and serum ferritin determinations in a population sample of women. Br J Haematol 85(4):787-798

37. van den Broek NR, Letsky EA, White SA, Shenkin A (1998) Iron status in pregnant women: which measurements are valid? Br J Haematol 103(3):817-824
38. Munoz M, Garcia-Erce JA, Remacha AF (2011) Disorders of iron metabolism. Part II: iron deficiency and iron overload. J Clin Pathol 64(4):287-296

39. WHO (2006) WHO recommendations on antenatal care for a positive pregnancy experience World Health Organization. WHO, Geneva

40. Breymann C, Honegger C, Hosli I, Surbek D (2017) Diagnosis and treatment of iron-deficiency anaemia in pregnancy and postpartum. Arch Gynecol Obstet 296(6):1229-1234. https://doi. org/10.1007/s00404-017-4526-2

41. Pavord S, Myers B, Robinson S, Allard S, Strong J, Oppenheimer C (2012) UK guidelines on the management of iron deficiency in pregnancy. Br J Haematol 156(5):588-600

42. Pena-Rosas JP, De-Regil LM, Dowswell T, Viteri FE (2012) Daily oral iron supplementation during pregnancy. Cochrane Database Syst Rev. https://doi.org/10.1002/14651858.cd004736. pub4

43. Gynecologists ACoO (2008) ACOG practice bulletin No. 95: anemia in pregnancy. Obstet Gynecol. https://doi.org/10.1097/ aog.0b013e3181809c0d

44. Wang C, Graham DJ, Kane RC, Xie D, Wernecke M, Levenson M, MaCurdy TE, Houstoun M, Ryan Q, Wong S, Mott K, Sheu TC, Limb S, Worrall C, Kelman JA, Reichman ME (2015) Comparative risk of anaphylactic reactions associated with intravenous iron products. JAMA 314(19):2062-2068. https://doi. org/10.1001/jama.2015.15572

45. Breymann C, Milman N, Mezzacasa A, Bernard R, Dudenhausen J (2017) Ferric carboxymaltose vs oral iron in the treatment of pregnant women with iron deficiency anemia: an international, open-label, randomized controlled trial (FER-ASAP). J Perinat Med 45(4):443-453. https://doi.org/10.1515/jpm-2016-0050

46. Christoph P, Schuller C, Studer H, Irion O, De Tejada BM, Surbek D (2012) Intravenous iron treatment in pregnancy: comparison of high-dose ferric carboxymaltose vs iron sucrose. J Perinat Med 40(5):469-474. https://doi.org/10.1515/jpm-2011-0231

47. Froessler B, Gajic T, Dekker G, Hodyl NA (2018) Treatment of iron deficiency and iron deficiency anemia with intravenous ferric carboxymaltose in pregnancy. Arch Gynecol Obstet. https ://doi.org/10.1007/s00404-018-4782-9

48. Froessler B, Collingwood J, Hodyl NA, Dekker G (2014) Intravenous ferric carboxymaltose for anaemia in pregnancy. BMC Pregnancy Childbirth 14:115. https://doi. org/10.1186/1471-2393-14-115

49. Frass K (2015) Postpartum haemorrhage is related to the haemoglobin levels at labor: Observational study. Alex J Med 51(333337):51. https://doi.org/10.1016/j.ajme.2014.12.002

50. Mavrides EAS, Chandraharan E, Collins P, Green L, Hunt BJ, Riris S, Thomson AJ (2017) Prevention and management of postpartum haemorrhage: green-top guideline No 52. BJOG 124(5):e106-e149. https://doi.org/10.1111/1471-0528.14178

51. Schlembach D, Helmer H, Henrich W, von Heymann C, Kainer F, Korte W, Kuhnert M, Lier H, Maul H, Rath W, Steppat S, Surbek D, Wacker J (2018) Peripartum Haemorrhage, Diagnosis and Therapy Guideline of the DGGG OEGGG and SGGG (S2 k Level, AWMF Registry No. 015/063, March 2016). Geburtshilfe und Frauenheilkunde 78(4):382-399

52. Ghezzi F, Cromi A, Uccella S, Raio L, Bolis P, Surbek D (2007) The Hayman technique: a simple method to treat postpartum haemorrhage. BJOG 114(3):362-365. https://doi.org/10.111 1/j.1471-0528.2006.01204.x

53. Soro MP, Denys A, de Rham M, Baud D (2017) Short and long term adverse outcomes after arterial embolisation for the treatment of postpartum haemorrhage: a systematic review. Eur Radiol 27(2):749-762. https://doi.org/10.1007/s0033 0-016-4395-2 
54. Hofmeyr GJ, Abdel-Aleem H, Abdel-Aleem MA (2013) Uterine massage for preventing postpartum haemorrhage. Cochrane Database Syst Rev. https://doi.org/10.1002/14651858.cd006431. pub3

55. McDonald S, Abbott JM, Higgins SP (2004) Prophylactic ergometrine-oxytocin versus oxytocin for the third stage of labour. Cochrane Database Syst Rev. https://doi.org/10.1002/14651858. cd000201.pub2

56. Tuncalp O, Hofmeyr GJ, Gulmezoglu AM (2012) Prostaglandins for preventing postpartum haemorrhage. Cochrane Database Syst Rev. https://doi.org/10.1002/14651858.cd000494.pub4

57. Gulmezoglu AM, Lumbiganon P, Landoulsi S, Widmer M, Abdel-Aleem H, Festin M, Carroli G, Qureshi Z, Souza JP, Bergel E, Piaggio G, Goudar SS, Yeh J, Armbruster D, Singata M, Pelaez-Crisologo C, Althabe F, Sekweyama P, Hofmeyr J, Stanton ME, Derman R, Elbourne D (2012) Active management of the third stage of labour with and without controlled cord traction: a randomised, controlled, non-inferiority trial. Lancet (London, England) 379(9827):1721-1727. https://doi.org/10.1016/ s0140-6736(12)60206-2

58. Begley CM, Gyte GM, Devane D, McGuire W, Weeks A (2011) Active versus expectant management for women in the third stage of labour. Cochrane Database Syst Rev. https://doi. org/10.1002/14651858.cd007412.pub3

59. Hutton EK, Hassan ES (2007) Late vs early clamping of the umbilical cord in full-term neonates: systematic review and meta-analysis of controlled trials. JAMA 297(11):1241-1252. https://doi.org/10.1001/jama.297.11.1241

60. Seitchik J (1967) Total body water and total body density of pregnant women. Obstet Gynecol 29(2):155-166

61. Theunissen IM, Parer JT (1994) Fluid and electrolytes in pregnancy. Clin Obstet Gynecol 37(1):3-15

62. Lindheimer MD, Katz AI (1973) Sodium and diuretics in pregnancy. New Engl J Med 288(17):891-894. https://doi. org/10.1056/nejm197304262881706

63. Lindheimer MB, WM. (1998) Renal function and volume homeostasis. In: Gleicher NB, Elkayam U (ed) Principles and Practice of Medical Therapy in Pregnancy, vol 3 edition. Appleton and Lange, Stanford CT, pp 1043-1052

64. Davison JM, Vallotton MB, Lindheimer MD (1981) Plasma osmolality and urinary concentration and dilution during and after pregnancy: evidence that lateral recumbency inhibits maximal urinary concentrating ability. Br J Obstet Gynaecol 88(5):472-479

65. Kobayashi T, Terao T, Maki M, Ikenoue T (2001) Diagnosis and management of acute obstetrical DIC. Semin Thromb Hemost 27(2):161-167. https://doi.org/10.1055/s-2001-14076

66. Le Bas A, Chandraharan E, Addei A, Arulkumaran S (2014) Use of the "obstetric shock index" as an adjunct in identifying significant blood loss in patients with massive postpartum hemorrhage. Int J Gynaecol Obstet 124(3):253-255. https://doi.org/10.1016/j. ijgo.2013.08.020

67. Luna GK, Maier RV, Pavlin EG, Anardi D, Copass MK, Oreskovich MR (1987) Incidence and effect of hypothermia in seriously injured patients. J Trauma 27(9):1014-1018

68. Thomas D, Wee M, Clyburn P, Walker I, Brohi K, Collins P, Doughty H, Isaac J, Mahoney PM, Shewry L (2010) Blood transfusion and the anaesthetist: management of massive haemorrhage. Anaesthesia 65(11):1153-1161

69. Stainsby D, MacLennan S, Thomas D, Isaac J, Hamilton PJ (2006) Guidelines on the management of massive blood loss. Br J Haematol 135(5):634-641. https://doi.org/10.111 1/j.1365-2141.2006.06355.x
70. Reviewers CIGA (1998) Human albumin administration in critically ill patients: systematic review of randomised controlled trials. BMJ 317(7153):235-240 (Clinical research ed)

71. Schierhout G, Roberts I (1998) Fluid resuscitation with colloid or crystalloid solutions in critically ill patients: a systematic review of randomised trials. BMJ 316(7136):961-964 (Clinical research ed)

72. Mousa HA, Blum J, Abou El Senoun G, Shakur H, Alfirevic Z (2014) Treatment for primary postpartum haemorrhage. Cochrane Database Syst Rev. https://doi.org/10.1002/14651858. cd003249.pub3

73. Rajan PV, Wing DA (2010) Postpartum hemorrhage: evidencebased medical interventions for prevention and treatment. Clin Obstet Gynecol 53(1):165-181. https://doi.org/10.1097/ GRF.0b013e3181ce0965

74. Dubber AH, McNicol GP, Douglas AS (1965) Amino methyl cyclohexane carboxylic acid (amcha), a new synthetic fibrinolytic inhibitor. Br J Haematol 11:237-245

75. Cesarman-Maus G, Hajjar KA (2005) Molecular mechanisms of fibrinolysis. Br J Haematol 129(3):307-321. https://doi.org/10.1 111/j.1365-2141.2005.05444.x

76. Ker K, Edwards P, Perel P, Shakur H, Roberts I (2012) Effect of tranexamic acid on surgical bleeding: systematic review and cumulative meta-analysis. BMJ 344:e3054. https://doi. org/10.1136/bmj.e3054 (Clinical research ed)

77. Shakur H, Roberts I, Bautista R, Caballero J, Coats T, Dewan Y, El-Sayed H, Gogichaishvili T, Gupta S, Herrera J, Hunt B, Iribhogbe $\mathrm{P}$, Izurieta $\mathrm{M}$, Khamis $\mathrm{H}$, Komolafe E, Marrero MA, Mejia-Mantilla J, Miranda J, Morales C, Olaomi O, Olldashi F, Perel P, Peto R, Ramana PV, Ravi RR, Yutthakasemsunt S (2010) Effects of tranexamic acid on death, vascular occlusive events, and blood transfusion in trauma patients with significant haemorrhage (CRASH-2): a randomised, placebo-controlled trial. Lancet (London, England) 376(9734):23-32. https://doi. org/10.1016/s0140-6736(10)60835-5

78. Collaborators WT (2017) Effect of early tranexamic acid administration on mortality, hysterectomy, and other morbidities in women with post-partum haemorrhage (WOMAN): an international, randomised, double-blind, placebo-controlled trial. Lancet (London, England) 389(10084):2105-2116. https://doi. org/10.1016/s0140-6736(17)30638-4

79. Roberts I, Shakur H, Afolabi A, Brohi K, Coats T, Dewan Y, Gando S, Guyatt G, Hunt BJ, Morales C, Perel P, Prieto-Merino D, Woolley T (2011) The importance of early treatment with tranexamic acid in bleeding trauma patients: an exploratory analysis of the CRASH-2 randomised controlled trial. Lancet (London, England) 377(9771):1096-1101. https://doi.org/10.1016/ s0140-6736(11)60278-x

80. Gayet-Ageron A, Prieto-Merino D, Ker K, Shakur H, Ageron FX, Roberts I (2018) Effect of treatment delay on the effectiveness and safety of antifibrinolytics in acute severe haemorrhage: a meta-analysis of individual patient-level data from 40138 bleeding patients. Lancet (London, England) 391(10116):125-132. https://doi.org/10.1016/s0140-6736(17)32455-8

81. Novikova N, Hofmeyr GJ, Cluver C (2015) Tranexamic acid for preventing postpartum haemorrhage. Cochrane Database Syst Rev. https://doi.org/10.1002/14651858.cd007872.pub3

82. Sentilhes L, Winer N, Azria E, Senat MV, Le Ray C, Vardon D, Perrotin F, Desbriere R, Fuchs F, Kayem G, Ducarme G, Doret-Dion M, Huissoud C, Bohec C, Deruelle P, Darsonval A, Chretien JM, Seco A, Daniel V, Deneux-Tharaux C (2018) Tranexamic acid for the prevention of blood loss after vaginal delivery. New Engl J Med 379(8):731-742. https://doi. org/10.1056/NEJMoa1800942 
83. Kozek-Langenecker SA, Afshari A, Albaladejo P, Santullano CA, De Robertis E, Filipescu DC, Fries D, Gorlinger K, Haas T, Imberger G, Jacob M, Lance M, Llau J, Mallett S, Meier J, Rahe-Meyer N, Samama CM, Smith A, Solomon C, Van der Linden P, Wikkelso AJ, Wouters P, Wyffels P (2013) Management of severe perioperative bleeding: guidelines from the European Society of Anaesthesiology. Eur J Anaesthesiol 30(6):270-382. https://doi.org/10.1097/EJA.0b013e32835f4d5b

84. Murphy MF, Wallington TB, Kelsey P, Boulton F, Bruce M, Cohen H, Duguid J, Knowles SM, Poole G, Williamson LM (2001) Guidelines for the clinical use of red cell transfusions. $\mathrm{Br}$ J Haematol 113(1):24-31

85. Services, UKB (2013) Handbook of transfusion medicine, 5th edn. TSO, Norwich

86. James AH, McLintock C, Lockhart E (2012) Postpartum hemorrhage: when uterotonics and sutures fail. Am J Hematol 87(Suppl 1):S16-S22. https://doi.org/10.1002/ajh.23156

87. Cortet M, Deneux-Tharaux C, Dupont C, Colin C, Rudigoz RC, Bouvier-Colle MH, Huissoud C (2012) Association between fibrinogen level and severity of postpartum haemorrhage: secondary analysis of a prospective trial. Br J Anaesth 108(6):984989. https://doi.org/10.1093/bja/aes096

88. de Lloyd L, Bovington R, Kaye A, Collis RE, Rayment R, Sanders J, Rees A, Collins PW (2011) Standard haemostatic tests following major obstetric haemorrhage. Int J Obstet Anesth 20(2):135-141. https://doi.org/10.1016/j.ijoa.2010.12.002

89. Charbit B, Mandelbrot L, Samain E, Baron G, Haddaoui B, Keita H, Sibony O, Mahieu-Caputo D, Hurtaud-Roux MF, Huisse MG, Denninger MH, de Prost D (2007) The decrease of fibrinogen is an early predictor of the severity of postpartum hemorrhage. J Thromb Haemost 5(2):266-273. https://doi.org/10.111 1/j.1538-7836.2007.02297.x

90. Bell SF, Rayment R, Collins PW, Collis RE (2010) The use of fibrinogen concentrate to correct hypofibrinogenaemia rapidly during obstetric haemorrhage. Int J Obstet Anesth 19(2):218223. https://doi.org/10.1016/j.ijoa.2009.08.004

91. Bolliger D, Szlam F, Levy JH, Molinaro RJ, Tanaka KA (2010) Haemodilution-induced profibrinolytic state is mitigated by fresh-frozen plasma: implications for early haemostatic intervention in massive haemorrhage. Br J Anaesth 104(3):318-325. https://doi.org/10.1093/bja/aeq001

92. Schochl H, Nienaber U, Hofer G, Voelckel W, Jambor C, Scharbert G, Kozek-Langenecker S, Solomon C (2010) Goal-directed coagulation management of major trauma patients using thromboelastometry (ROTEM)-guided administration of fibrinogen concentrate and prothrombin complex concentrate. Critical Care (London, England) 14(2):R55. https://doi.org/10.1186/cc8948

93. Butwick AJ (2013) Postpartum hemorrhage and low fibrinogen levels: the past, present and future. Int J Obstet Anesth 22(2):8791. https://doi.org/10.1016/j.ijoa.2013.01.002

94. Ahmed S, Harrity C, Johnson S, Varadkar S, McMorrow S, Fanning R, Flynn CM, Byrne BM (2012) The efficacy of fibrinogen concentrate compared with cryoprecipitate in major obstetric haemorrhage-an observational study. Transfus Med 22(5):344349. https://doi.org/10.1111/j.1365-3148.2012.01178.x

95. Fenger-Eriksen $C$, Lindberg-Larsen M, Christensen AQ, Ingerslev J, Sorensen B (2008) Fibrinogen concentrate substitution therapy in patients with massive haemorrhage and low plasma fibrinogen concentrations. Br J Anaesth 101(6):769-773. https ://doi.org/10.1093/bja/aen270

96. Weinkove R, Rangarajan S (2008) Fibrinogen concentrate for acquired hypofibrinogenaemic states. Transfus Med 18(3):151157. https://doi.org/10.1111/j.1365-3148.2008.00854.x

97. Ekelund K, Hanke G, Stensballe J, Wikkelsoe A, Albrechtsen CK, Afshari A (2015) Hemostatic resuscitation in postpartum hemorrhage a supplement to surgery. Acta Obstet Gynecol Scand 94(7):680-692. https://doi.org/10.1111/aogs.12607

98. Girard T, Mortl M, Schlembach D (2014) New approaches to obstetric hemorrhage: the postpartum hemorrhage consensus algorithm. Curr Opin Anaesthesiol 27(3):267-274. https://doi. org/10.1097/aco.0000000000000081

99. Stensballe J, Ostrowski SR, Johansson PI (2014) Viscoelastic guidance of resuscitation. Curr Opin Anaesthesiol 27(2):212218. https://doi.org/10.1097/aco.0000000000000051

100. Ahonen J (2012) The role of recombinant activated factor VII in obstetric hemorrhage. Curr Opin Anaesthesiol 25(3):309-314. https://doi.org/10.1097/ACO.0b013e3283532007

101. Lavigne-Lissalde G, Aya AG, Mercier FJ, Roger-Christoph S, Chauleur C, Morau E, Ducloy-Bouthors AS, Mignon A, Raucoules M, Bongain A, Boehlen F, de Moerloose P, Bouvet S, Fabbro-Peray P, Gris JC (2015) Recombinant human FVIIa for reducing the need for invasive second-line therapies in severe refractory postpartum hemorrhage: a multicenter, randomized, open controlled trial. J Thrombos Haemost 13(4):520-529. https://doi.org/10.1111/jth.12844

102. Huber AW, Raio L, Alberio L, Ghezzi F, Surbek DV (2011) Recombinant human factor VIIa prevents hysterectomy in severe postpartum hemorrhage: single center study. J Perinat Med 40(1):43-49. https://doi.org/10.1515/jpm.2011.109

103. Gynecologists. ACoOa (2006) ACOG practice bulletin: clinical management guidelines for obstetrician-gynecologists number 76, october 2006: postpartum hemorrhage. Obstet Gynecol 108(4):1039-1047

104. Lalonde A, Daviss BA, Acosta A, Herschderfer K (2006) Postpartum hemorrhage today: ICM/FIGO initiative 2004-2006. Int J Gynaecol Obstet 94(3):243-253. https://doi.org/10.1016/j. ijgo.2006.04.016

105. WHO (2009) WHO guidelines for the management of postpartum haemorrhage and retained placenta World Health Organization. WHO, Geneva

106. Lee HY, Shin JH, Kim J, Yoon HK, Ko GY, Won HS, Gwon DI, Kim JH, Cho KS, Sung KB (2012) Primary postpartum hemorrhage: outcome of pelvic arterial embolization in 251 patients at a single institution. Radiology 264(3):903-909. https://doi. org/10.1148/radiol.12111383

107. Fargeaudou Y, Morel O, Soyer P, Gayat E, Sirol M, Boudiaf M, Dahan H, Barranger E, Mebazaa A, le Dref O (2010) Persistent postpartum haemorrhage after failed arterial ligation: value of pelvic embolisation. Eur Radiol 20(7):1777-1785. https://doi. org/10.1007/s00330-010-1713-y

108. Matsubara S, Yano H, Ohkuchi A, Kuwata T, Usui R, Suzuki M (2013) Uterine compression sutures for postpartum hemorrhage: an overview. Acta Obstet Gynecol Scand 92(4):378385. https://doi.org/10.1111/aogs. 12077

109. Kayem G, Kurinczuk JJ, Alfirevic Z, Spark P, Brocklehurst P, Knight M (2011) Uterine compression sutures for the management of severe postpartum hemorrhage. Obstet Gynecol 117(1):14-20

110. Doumouchtsis SK, Nikolopoulos K, Talaulikar V, Krishna A, Arulkumaran S (2014) Menstrual and fertility outcomes following the surgical management of postpartum haemorrhage: a systematic review. BJOG 121(4):382-388. https://doi. org/10.1111/1471-0528.12546 (An international journal of obstetrics and gynaecology)

111. Joshi VM, Otiv SR, Majumder R, Nikam YA, Shrivastava M (2007) Internal iliac artery ligation for arresting postpartum haemorrhage. BJOG 114(3):356-361. https://doi.org/10.111 1/j.1471-0528.2006.01235.x (An international journal of obstetrics and gynaecology)

112. Khan KS, Moore PAS, Wilson MJ, Hooper R, Allard S, Wrench I, Beresford L, Roberts TE, McLoughlin C, Geoghegan J, 
Daniels JP, Catling S, Clark VA, Ayuk P, Robson S, GaoSmith F, Hogg M, Lanz D, Dodds J (2017) Cell salvage and donor blood transfusion during cesarean section: a pragmatic, multicentre randomised controlled trial (SALVO). PLoS Med 14(12):e1002471. https://doi.org/10.1371/journal.pmed.10024 71

113. Clyburn PA (2004) Early thoughts on 'Why Mothers Die 20002002'. Anaesthesia 59(12):1157-1159. https://doi.org/10.111 1/j.1365-2044.2004.04060.x

114. Munoz M, Pena-Rosas JP, Robinson S, Milman N, Holzgreve W, Breymann C, Goffinet F, Nizard J, Christory F, Samama CM, Hardy JF (2018) Patient blood management in obstetrics: management of anaemia and haematinic deficiencies in pregnancy and in the post-partum period: NATA consensus statement. Transfus Med 28(1):22-39. https://doi.org/10.1111/tme.12443

115. Koshy M, Burd L, Wallace D, Moawad A, Baron J (1988) Prophylactic red-cell transfusions in pregnant patients with sickle cell disease. A randomized cooperative study. New Engl J Med 319(22):1447-1452. https://doi.org/10.1056/nejm19881201319 2204

116. Sifakis S, Pharmakides G (2000) Anemia in pregnancy. Ann N Y Acad Sci 900:125-136

117. Carles G, Tobal N, Raynal P, Herault S, Beucher G, Marret H, Arbeille P (2003) Doppler assessment of the fetal cerebral hemodynamic response to moderate or severe maternal anemia. Am J Obstet Gynecol 188(3):794-799

118. Emmert MY, Salzberg SP, Theusinger OM, Felix C, Plass A, Hoerstrup SP, Falk V, Gruenenfelder J (2011) How good patient blood management leads to excellent outcomes in Jehovah's witness patients undergoing cardiac surgery. Interact Cardiovas Thorac Surg 12(2):183-188. https://doi.org/10.1510/icvts .2010 .242552

119. Albacar G, Sans T, Martin-Santos R, Garcia-Esteve L, Guillamat R, Sanjuan J, Canellas F, Gratacos M, Cavalle P, Arija V, Gaviria A, Gutierrez-Zotes A, Vilella E (2011) An association between plasma ferritin concentrations measured $48 \mathrm{~h}$ after delivery and postpartum depression. J Affect Disord 131(1-3):136-142. https ://doi.org/10.1016/j.jad.2010.11.006

120. Milman N (2011) Postpartum anemia I: definition, prevalence, causes, and consequences. Ann Hematol 90(11):1247-1253. https://doi.org/10.1007/s00277-011-1279-z

121. Milman N (2012) Postpartum anemia II: prevention and treatment. Ann Hematol 91(2):143-154. https://doi.org/10.1007/ s00277-011-1381-2

122. Bergmann RL, Richter R, Bergmann KE, Dudenhausen JW (2010) Prevalence and risk factors for early postpartum anemia. Eur J Obstet Gynecol Reprod Biol 150(2):126-131. https://doi. org/10.1016/j.ejogrb.2010.02.030

123. Milman N, Agger AO, Nielsen OJ (1991) Iron supplementation during pregnancy. Effect on iron status markers, serum erythropoietin and human placental lactogen. A placebo controlled study in 207 Danish women. Danish Med Bull 38(6):471-476

124. Patel A, Goudar SS, Geller SE, Kodkany BS, Edlavitch SA, Wagh K, Patted SS, Naik VA, Moss N, Derman RJ (2006) Drape estimation vs. visual assessment for estimating postpartum hemorrhage. Int J Gynaecol Obstetr 93(3):220-224

125. Allary J, Soubirou JF, Michel J, Amiel I, Silins V, Brasher C, Oury JF, Nivoche Y, Dahmani S (2013) An individual scoring system for the prediction of postpartum anaemia. Ann Fr Anesth Reanim 32(1):e1-e7. https://doi.org/10.1016/j.annfa r.2012.11.002

126. Krafft A, Huch R, Breymann C (2003) Impact of parturition on iron status in nonanaemic iron deficiency. Eur J Clin Invest 33(10):919-923

127. Murray-Kolb LE, Beard JL (2009) Iron deficiency and child and maternal health. Am J Clin Nutr 89(3):946s-950s. https://doi. org/10.3945/ajen.2008.26692D

128. Milman N (2008) Prepartum anaemia: prevention and treatment. Ann Hematol 87(12):949-959. https://doi.org/10.1007/s0027 7-008-0518-4

129. Perez EM, Hendricks MK, Beard JL, Murray-Kolb LE, Berg A, Tomlinson M, Irlam J, Isaacs W, Njengele T, Sive A, VernonFeagans L (2005) Mother-infant interactions and infant development are altered by maternal iron deficiency anemia. J Nutr 135(4):850-855. https://doi.org/10.1093/jn/135.4.850

130. WHO (2016) Guideline: iron supplementation in postpartum women. WHO, Geneva

131. Haider BA, Olofin I, Wang M, Spiegelman D, Ezzati M, Fawzi WW (2013) Anaemia, prenatal iron use, and risk of adverse pregnancy outcomes: systematic review and meta-analysis. BMJ 346:f3443. https://doi.org/10.1136/bmj.f3443 (Clinical research ed)

132. Pena-Rosas JP, De-Regil LM, Gomez Malave H, Flores-Urrutia MC, Dowswell T (2015) Intermittent oral iron supplementation during pregnancy. The Cochrane database of systematic reviews. https://doi.org/10.1002/14651858.cd009997.pub2

133. Pena-Rosas JP, De-Regil LM, Garcia-Casal MN, Dowswell $\mathrm{T}$ (2015) Daily oral iron supplementation during pregnancy. The Cochrane database of systematic reviews. https://doi. org/10.1002/14651858.cd004736.pub5

134. Rathod S, Samal SK, Mahapatra PC, Samal S (2015) Ferric carboxymaltose: a revolution in the treatment of postpartum anemia in Indian women. Int J Appl Basic Med Res 5(1):25-30. https:// doi.org/10.4103/2229-516x.149230

135. Sultan P, Bampoe S, Shah R, Guo N, Estes J, Stave C, Goodnough T, Halpern S, Butwick AJ (2018) Oral versus intravenous iron therapy for postpartum anemia: a systematic review and meta-analysis. Am J Obstet Gynecol. https://doi.org/10.1016/j. ajog.2018.12.016

136. Weiss G, Goodnough LT (2005) Anemia of chronic disease. New Engl J Med 352(10):1011-1023. https://doi.org/10.1056/NEJMr a041809

Publisher's Note Springer Nature remains neutral with regard to jurisdictional claims in published maps and institutional affiliations. 